tially available, but has reference to peace-time conditions. In war-time, consumption by the fighting services will obviously increase even beyond the figure for 1938 when Germany was mobilizing, but at the same time civilian consumption will drop on account of the stringent rationing schemes now in force; also less oil will be used by Germany's mercantile marine, the activities of which have been so severely restricted of late. It is probable, therefore, that Germany's potential resources of oil will be sufficient for her war-time needs, and as reserves are available to supplement home production until such time as all projected plants are in operation, it is unlikely that she will go short of oil, unless through drastic changes in the international situation.

\section{Folsom Man: Further Investigation in Colorado}

A Funtrien season of excavation on the Lindenmeier site in northern Colorado has again failed to produce any trace of skeletal remains of Folsom man. Until such ovidence is forthcoming, and on the assumption that it will afford some certain indication of the relation of the authors of the culture to the Amerindian peoples, the Folsom industry, with its distinctive characteristics, hangs in tho air. The geological interpretation of the Folsom deposits on the Lindenmeier site assigns them to the last phase of the glacial period at an approximate dating of 12,000-25,000 years ago, and an association with an extinct fauna including mammoth, camel and oxtinct forms of bison. In the courso of excavations carried out by Dr. F. H. H. Roborts, jun., in the past summer, the fifth season of his investigations on the site, it is reported in a statement issued by the Smithsonian Institution of Washington, that among animal bones, which had been chopped and split by man, was found the skull of an extinct bison measuring 36 inches between the tips of the horn cores-fully a foot wider than the spread between the horns in the modern species. In four months' work Dr. Roberts opened up a new section of the site over an area of some $45 \mathrm{ft}$. by $60 \mathrm{ft}$. to an average depth of six feet. His finds, in addition to the characteristic projectile points and previously lnown artefacts, included new forms of knives and scrapers, two to three times as large as those found before. A new feature in the culture is the bone bead, not hitherto found in Folsom deposits. Of those found here, one shows definite ornamentation in the form of $a$ simple geometric design scratched on the surface.

\section{Mental Hygiene in Old Age}

IN a paper on this subject read before the Section on Care of the Aged, Welfare Council, New York City (Mental Health, 23, 257; 1939), Dr. George Lawton, psychological adviser to the Andrew Freedman Home, New York City, maintains that there is no group of persons whose mental welfare is more neglected than that of old people. This indifference, he declares, is world-wide even in countries with advanced social services. Although there has been for many years a guidance clinic for the aged in San
Francisco, no definito steps have been taken for establishing a similar one in Now York. Dr. Lawton asserts that what little knowledge we have of old people is based on pathological material, while we possess very littlo information about non-psychotic old persons. Ho suggests that the psychological difficulties presented by aged peoplo should be clissified as follows: (I) the problems of nourotic, borderline psychotic, psychotic, feeble-minded, and deterioriated individuals; (2) the minor mal-adjustments of fairly adequato old peoplo caused by excessive economic pressures and inhibitory social attitudes; (3) the stresses and strains of persons undergoing normal mental and emotional decline. According to Dr. Irawton, the management of the problem of senescence should include the following measures, among others: (1) intensive, systematic studies over long periods of time, of the mental abilities, interests, recreations, emotions and personalities of larger groups of men and women in town and country in each decado from forty to sixty, (2) when such facts have been collected, guidance clinics should bo set up to function in a similar manner to child guidance clinics; (3) courses in geriatries should bo established in the medical schools to give future physicians a better understanding of tho effects of mental attitudes on the bodily ailments of tho aged.

\section{Wild-life Restoration in the United States}

IN tho United States, as in other progressive countries, the existence of many wild creatures has been threatened by the appropriation of lands for farming and industrial purposes, the destruction of living places and breeding places, and tho gradual disappearance of natural food and cover. To check this decrease of wild-life, the Foderal Government passed two years ago ono of the most beneficial measures of recent years, tho Federal Aid to IVild. life Restoration Act, briefly known as the Pittman. Robertson Act of 1937. The co-operative scheme which it envisages is one that might well be adopted in other countries, and a summary of its provisions and explanation of the co-operation which it secks are now given by Albert M. Day (U.S. Dept. Agric. Misc. Pub. No. 350 ; 1939). The Act recognizes the fundamental principlo that wild-life is linked with tho land, and aims at tho restoration of suitable environment in which wild birds and mammals may live and multiply. 'The Federal Government is willing to contribute materially towards this restoration programme, since it is known that individual States have been unable to cope with the situation because of lack of funds. But a State to qualify for a sharo of the grant-up to 75 per cent of the cost of work performed on approved projects-must have passed laws for the conservation of wild-life, which shall include a prohibition against diverting fees paid by hunters to any other purpose than the administration of the State fish and gamo department. Already the Act appears to bo working effectively. The grand total allocated for conservation projects in 1939 was 1;186,666 dollars, of which State legislatures 